\title{
Foot-and-mouth disease virus carrier status in Bos grunniens yaks
}

\author{
Huiyun Chang*, Yanbin Ma, Tong Lin, Guozheng Cong, Junzheng Du and Jinling Ma
}

\begin{abstract}
Background: The carrier status of foot-and-mouth disease virus (FMDV) is complicated, and the role of carrier animals in virus transmission is controversial. To investigate the carrier status of FMDV in animals that live in high altitude, Bos grunniens yaks were infected experimentally with FMDV O/Akesu/58.

Results: All of the yaks showed clinical signs of foot-and-mouth disease (FMD). Total antibody levels against FMDV measured by liquid-phase blocking enzyme-linked immunosorbent assay (LPB-ELISA) and antibody levels against nonstructural proteins (NSP) showed dynamic changes. Three of the five yaks were indentified as carrier animals by RT-PCR method, and the OP fluids from carrier yaks can cause cytopathic effect (CPE) on BHK-21 cells. At last, five persistent infection strains were isolated. Nucleotide mutations of VP1 gene were analyzed.

Conclusions: After infected with FMDV, all of the yaks showed typical clinical signs. Yaks can keep carrier status for at least 8 months. Total antibody levels against FMDV measured by LPB-ELISA and antibody levels against NSP were at high level for carrier yaks. Sequence alignment of the five isolated strains showed obvious gene and protein mutations.
\end{abstract}

Keywords: FMDV, Yak, Gene mutation, Carrier status

\section{Background}

Foot-and-mouth disease (FMD) is one of the most contagious viral diseases of cloven-hoofed livestock including cattle, swine, sheep, and goat, as well as over 70 species of wild animals. The disease leads to high mortality in young animals, high morbidity, and loss in productivity [1-3]. Foot-and-mouth disease virus (FMDV), the first demonstrated filterable agent causing animal disease, is belong to the Aphtovirus genus of the Picornaviridae family, and contains a single-stranded positive-sense RNA genome of about 8500 nucleotides [4]. As is the lack of error correction mechanism during RNA replication, FMDV has a very high mutation rate ranging from $10^{-3}$ to $10^{-5}$ per nucleotide site per genome replication, which results in the presence of seven serotypes, multiple subtypes, and variants $[5,6]$.

Following acute phase of FMDV infection or vaccination, animals may experience persistent infection without clinical signs, and these animals are defined as

\footnotetext{
* Correspondence: changhuiyun@126.com

State Key Laboratory of Veterinary Etiological Biology, National Foot and Mouth Disease Reference Laboratory, Lanzhou Veterinary Research Institute, Chinese Academy of Agricultural Sciences, Lanzhou 730046, China
}

carrier animals. The duration of the carrier status was influenced by many factors including host species, and breed [7]. Carrier animals are those from which live virus can be recovered longer than 28 days after exposure [8]. Till now, virus isolation from esophageal-pharyngeal (OP) fluids was thought to be the most sensitive method to detect carrier animals $[9,10]$. Molecular techniques for the diagnosis of persistent infection have been used which offered a potential ability to improve the detection of a low genome copy number in clinical samples. Several assays were described which utilized reverse transcription-polymerase chain reaction (RT-PCR) for the detection of FMDV [11,12]. With PCR and dotblot hybridization, FMDV RNA was detected in probang samples in which virus could be no longer isolated [13-18]. African cattle was shown to excrete FMDV over three years, sheep for up to one year, goats for up to four months, and African buffalo for at least five years $[7,19,20]$. No FMDV was detected in pigs from the OP fluids which was sampled 28 days after infection, and considered to be non-carriers of FMDV. However, a study of the replication analysis of FMDV in swine lymphoid tissue might indicate a putative carrier stage in 
pigs [21]. Animals used in previous studies were almost living in a comparative friendly environment in low altitude. The friendly environment was shown as: small one day temperature difference, high oxygen concentration, and proper atmospheric pressure. Phenotype was influenced by gene and environment, so animals in high altitude regions showed different abilities to oxygen concentration and temperature change. Other abilities also showed different, such as the immune response $[22,23]$. This may result in different evolution pressure on pathogens invading animals.

To investigate whether animals in high altitude regions experience a different carrier status and gene mutation of FMDV, yaks, a special species living in Qinghai-Tibet Plateau were infected experimentally with the O/Akesu/58. OP fluids and blood were sampled for detection of virus and antibodies level. Results showed that yaks can carry FMDV for at least eight months, and nucleotide, amino acid (AA) sequence of VP1 shared some common mutations in isolated strains [11]. What's more, carrier yaks always had a high antibody level.

\section{Results}

\section{Clinical signs of yaks}

All of the five yaks experienced acute phase, and showed typical FMDV clinical signs. Fever and primary vesicles were detected $18 \mathrm{~h}$ after inoculation. Twenty-four hours after inoculation, body temperature was $41.2^{\circ} \mathrm{C}$, and the yaks showed more vesicles on the surface of tongue. Forty hours after inoculation, some vesicles began to break up, and vesicular lesions were detected on hoof crown. What's more, body temperature began to decline. One week after inoculation, yaks came to recovery period.

\section{Antibody levels during the carrier status and the detection of virus}

Total antibody levels against FMDV by LPB-ELISA were shown in Figure 1. Total antibodies of the five yaks

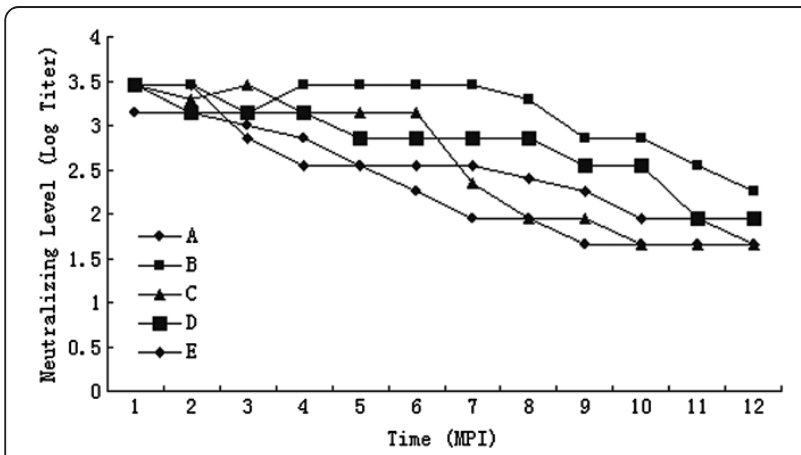

Figure 1 Total antibodies levels curve of the yaks. The antibody level was measured by log2 titer of LBP-ELSA. MPI: month postinfection. showed differences between individuals. All of the yaks maintained a high antibody level for at least for 6 months. Total antibody level of yak $\mathrm{C}$ had declined obviously since 7 month post-infection (MPI), while yak B maintained a relatively high level until 8 MPI. 3ABC antibody levels of the five yaks were measured by indirect ELISA (Figure 2), and also showed individual difference. Two MPI, 3ABC antibody level reached the peak, and then declined quickly. Yak B kept a high level, while yak $\mathrm{A}$ and $\mathrm{C}$ showed relatively low antibody levels.

Presence of virus was identified by RT-PCR and CPE (Table 1). The OP fluids were used for RT-PCR detection, and inoculated into BHK-21 cells to isolate the virus strain. From Table 1, we can see that OP fluids which were detected positive by RT-PCR can all lead to CPE within ten times' cell infection cycle, which indicated the existence of live viruses. No live virus was detected in yak A and C, while yak B kept the longest carrier status. No virus was detected in samples from 10 , 11, and 12 MPI. This indicated that carrier period of yaks is at least 8 months.

Obviously, there was no certain correlation between antibody level and the existence of virus. But total antibodies and antibody against NSP were at high level for carrier yaks. In this study, when the $\mathrm{OD}_{492}$ value of NSP antibody level was above 1.2, and the titer of total antibodies level was higher than 1:708, yak may experience carrier status.

\section{Nucleotide and AA mutation in VP1}

The RT-PCR products of VP1 gene were sequenced. Pairwise genetic distances of gene and protein sequence distance were shown (Table 2; Table 3). Compared with $\mathrm{O} /$ Akesu/58, the isolated strains showed 36 nucleotide mutations. The five isolated strains shared 26 of $36 \mathrm{nu}-$ cleotide mutations. Fourteen AA mutations were found

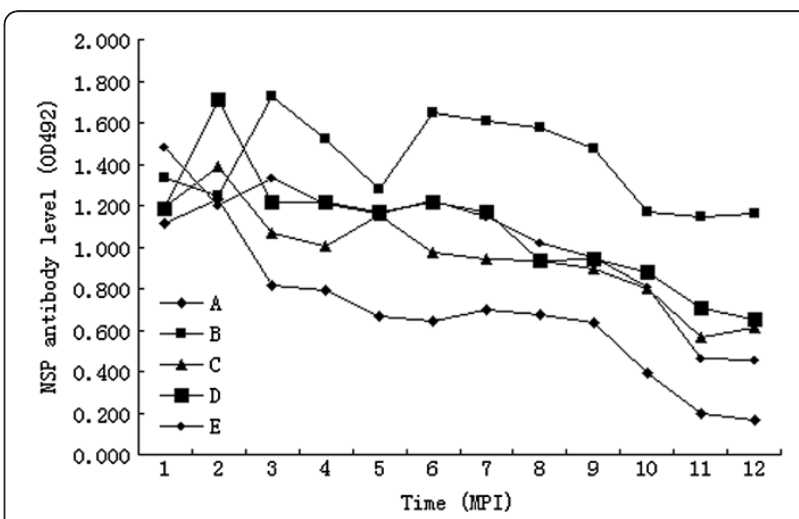

Figure 2 The $3 A B C$ antibody levels curve of the yaks. The $3 A B C$ antibody level was measured by the OD value of Indirect-ELISA. A-E indicated the identity of the yaks. And the $\mathrm{OD}_{492}$ value of blanking control was 0.2. MPI: month post-infection. 
Table 1 The CPE and RT-PCR results of the OP fluids

\begin{tabular}{|c|c|c|c|c|c|c|c|c|c|c|}
\hline \multirow[t]{2}{*}{ MPI } & \multicolumn{2}{|c|}{ A } & \multicolumn{2}{|c|}{ B } & \multicolumn{2}{|c|}{ C } & \multicolumn{2}{|c|}{ D } & \multicolumn{2}{|c|}{$E$} \\
\hline & CPE & RT-PCR & CPE & RT-PCR & CPE & RT-PCR & CPE & RT-PCR & CPE & RT-PCR \\
\hline 1 & - & - & + & + & - & - & - & - & - & - \\
\hline 2 & - & - & + & + & - & - & - & - & + & + \\
\hline 3 & - & - & - & - & - & - & - & - & - & - \\
\hline 4 & - & - & - & - & - & - & - & - & - & - \\
\hline 5 & - & - & - & - & - & - & - & - & - & - \\
\hline 6 & - & - & - & - & - & - & + & + & - & - \\
\hline 7 & - & - & - & - & - & - & - & - & - & - \\
\hline 8 & - & - & + & + & - & - & - & - & - & - \\
\hline 9 & - & - & - & - & - & - & - & - & - & - \\
\hline 10 & - & - & - & - & - & - & - & - & - & - \\
\hline 11 & - & - & - & - & - & - & - & - & - & - \\
\hline 12 & - & - & - & - & - & - & - & - & - & - \\
\hline
\end{tabular}

" + " the existence of CPE or the gene was detected by RT-PCR; " " " CPE was not observed or the gene was not detected by RT-PCR. MPI: month post-infection The A-E indicated the identity of the yaks, and 1-12 means the MPI of sampling.

at translated amino acid sequences. And the five isolated strains shared 8 of 14 AA mutations.

\section{Discussion}

Similar with previous studies [24,25], yaks can experience acute phase and persistent infection after high-dose FMDV was inoculated. Acute phase or vaccination could cause persistent infection, so some people think that immune status of animals may control virus replication level $[1,10,26-28]$. Here, we find that yaks detected with the existence of virus always had a high antibody level, which indicated that the existence of high antibody level can protect animals from clinical signs, but not enough to clear virus completely. What's more, virus was not regularly detected during persistent infection. Obvious gene and protein mutations of VP1 were observed, so we postulated that the variation of VP1 may be a possible reason for carrier status.

The role of carrier animals in virus transmission is undetermined. The transmission from African buffalo to cattle has obtained experimentally which indicated that

Table 2 The gene similarity of aligned sequences

\begin{tabular}{ccccccc}
\hline & Akesu/58 & B01 & B02 & B08 & D06 & E02 \\
\hline Akesu/58 & $* * *$ & 95.1 & 95.1 & 95.3 & 95.3 & 95.8 \\
B01 & 5 & $* * *$ & 99.1 & 99.2 & 99.2 & 99.4 \\
B02 & 5 & 0.9 & $* * *$ & 99.5 & 99.5 & 99.4 \\
B08 & 4.9 & 0.8 & 0.5 & $* * *$ & 99.7 & 99.5 \\
D06 & 4.9 & 0.8 & 0.5 & 0.3 & $* * *$ & 99.5 \\
E02 & 4.4 & 0.6 & 0.6 & 0.5 & 0.5 & $* * *$
\end{tabular}

The sequences were aligned by Clustal W Method in MegAlign. The upper triangle shows the Percent Similarity of gene sequences of the five isolated strains and O/Akesu/58, while the lower triangle shows the Percent Divergence. carrier state can be a source of infection $[29,30]$. However, no experimental evidence showed that carrier cattle or sheep can transmit virus to uninfected animals. The persistent infection can lead to gene mutation [31], possibly being responsible for the generation of new viral variants in the field. The research of persistent infection and gene mutation of FMDV is a complicated and timeconsuming work. From this research, we can conclude that yaks can keep carrier status for at least 8 months. To further study the phenomenon, virulence of the isolated strains to other species and reconstruct of these mutation sits will be the aim of future work.

\section{Conclusions}

After infected with FMDV, all of the yaks showed typical clinical signs. Yaks can keep carrier status for at least 8 months. Total antibody levels against FMDV measured by LPB-ELISA and antibody levels against NSP were at high level for carrier yaks. Sequence alignment of the five isolated strains showed obvious gene and protein mutations.

\section{Materials and methods \\ Virus and virus inoculation}

In this study, O/Akesu/58 (serotype $\mathrm{O}$, isolated in Akesu, XinJiang, 1958) which was adapted to suckling mouse and BHK-21 was used. Per Yak was inoculated under the mucosa of tongue with a dose of $10^{4} \mathrm{ID}_{50}$ tested in cattle.

\section{Yaks and treatment}

Five 1-year-old yaks (Bos grunniens) were used in this study. The yaks were free of antibodies against FMDV, and the OP fluids of yaks were free of FMDV by RT-PCR. 
Table 3 The protein similarity of aligned sequences

\begin{tabular}{ccccccc}
\hline & Akesu//58 & B01 & B02 & B08 & D06 & E02 \\
\hline Akesu//58 & $* * *$ & 94.4 & 94.8 & 95.3 & 94.8 & 95.8 \\
B01 & 5.9 & *** & 98.6 & 99.1 & 98.6 & 98.6 \\
B02 & 5.4 & 1.4 & $* * *$ & 99.5 & 99.1 & 99.1 \\
B08 & 4.9 & 0.9 & 0.5 & $* * *$ & 99.5 & 99.5 \\
D06 & 5.4 & 1.4 & 0.9 & 0.5 & $* * *$ & 99.1 \\
E02 & 4.4 & 1.4 & 0.9 & 0.5 & 0.9 & $* * *$
\end{tabular}

The sequences were aligned by Clustal W Method in MegAlign. The upper triangle shows the Percent Similarity of protein sequences of the five isolated strains and $\mathrm{O} / \mathrm{Akesu} / 58$, while the lower triangle shows the Percent Divergence.

The yaks were random named from A to $\mathrm{E}$. The five yaks were all inoculated with O/Akesu/58. The yaks were housed in Biological safety protection third-level (BSL-3) animal homes of Lanzhou Veterinary Research Institute. All tests were approved by the Animal Ethics Committee of the Animal Sciences Group of Gansu Province.

\section{Tissue samples and treatment}

The yaks were sampled at 1 MPI, and kept being sampled monthly for 12 months. Each sample was given an identity number consisting of one letter and two numbers. The letter means the identity of the yak, and the two numbers represents the time of sampling. For example, E03 means that the sample was collected from yak E 3 MPI. Animals were kept being fasted for 12 hours before sampled. Five milliliter OP fluids and $10 \mathrm{ml}$ blood were taken from each yak. The OP fluids were moved into a centrifuge tube with equal volume of PBS/TTE. Then the OP fluids were emulsified and centrifuged at $3000 \mathrm{rpm}$. The supernatant was divided into aliquot, and stored at $-70^{\circ} \mathrm{C}$. The blood samples were treated with the procedure of $4^{\circ} \mathrm{C} 1 \mathrm{~h}, 37^{\circ} \mathrm{C} 1 \mathrm{~min}$, and then centrifuged at $4^{\circ} \mathrm{C} 5000 \mathrm{rpm}$ for $10 \mathrm{~min}$. The serum was stored at $-70^{\circ} \mathrm{C}$.

\section{Cells and cell infection}

Baby hamster kidney (BHK-21) cells were cultured in Dulbecco's modified Eagle medium (DMEM; Invitrogen) supplemented with $10 \%$ fetal bovine serum (FBS; Hyclone). The well grown BHK-21 cells in $25 \mathrm{ml}$ culture plate were inoculated with $1 \mathrm{ml}$ OP fluids. Four milliliter sustaining medium was added per plate after $45 \mathrm{~min}$ adsorption. Cells were maintained at $37^{\circ} \mathrm{C}$ in humidified $5 \% \mathrm{CO}_{2}$ environment for no more than $72 \mathrm{~h}$. Cell status was observed every $3 \mathrm{~h}$, and harvested when 95\% CPE appeared. The infected cells should be harvested within $72 \mathrm{~h}$. Cells without CPE would go on next cell infection cycle after three times of freeze-thaw [32]. Cell infection cycles were done no more than 10 times for each sample. Samples were identified as negative when no CPE was detected within 10 times of cell infection cycles.

\section{RNA extraction and RT-PCR detection}

The treated OP fluids were used for RNA extraction with RNeasy Mini Kit (QIAGEN). The existence of viral RNA was measured by RT-PCR assay with the primers for VP1. Primers were designed based on the genome sequence of O/Akesu/58 with Oligo 7.0. The product length is $639 \mathrm{bp}$. The primers were as following:

\section{Forward primer 5'-TAGTGCGGTTAAAGCTTTG-3', Reverse primer 5'-GACATGTCCTCCTGCATCTG-3'.}

The reverse transcription was performed in the volume of $20 \mu \mathrm{l}$ containing $2 \mu \mathrm{g}$ of total RNA, $0.5 \mathrm{mM}$ dNTP each, $2.5 \mu \mathrm{M}$ reverse primer, $4 \mu \mathrm{l} 5 \times$ AMV buffer, and $0.5 \mathrm{U} / \mu \mathrm{l}$ AMV reverse transcriptase (TaKaRa).

The PCR was performed in the volume of $50 \mu$ l. The final concentration of each reagent was: $0.4 \mathrm{mM} d N T P$, $0.4 \mu \mathrm{M}$ forward primer, $0.4 \mu \mathrm{M}$ reverse primer, cDNA $6 \mu \mathrm{l}, 10 \times$ LA Buffer $5 \mu \mathrm{l}$, and LA Taq enzyme $0.05 \mathrm{U} / \mu \mathrm{l}$ (TaKaRa).

\section{T-A clone and sequencing of VP1}

The RT-PCR products of VP1 were purified with Gel DNA Extraction Kit (QIAGEN). T-A clone was performed with pGEM-T Easy vector (Promega). The ligase product was transformed into competent cells DH5 $\alpha$. The plasmids extracted with Plasmid Purification Kit (TaKaRa) were identified with PCR. The positive plasmid was sequenced by ABI-PRISM3730.

\section{Antibody detection}

The total FMDV antibodies were detected with a commercial LPB-ELISA kit, and all procedures were performed according to the manufacturer's instructions [33].

To detect the antibody level against 3ABC NSP of FMDV, a commercially available kit was used, and all procedures were carried out by following the manufacturer's instructions [34].

\section{Sequence analysis}

The nucleotide and protein sequences of the five isolate strains (GenBank ID: JQ693472, JQ693473, JQ693474, JQ693475, JQ693476) and O/Akesu/58 (GenBank ID: AJ131469) were aligned by MegAlign in DNAstar, and pairwise genetic distances were computed.

\section{Competing interests}

The authors declare that they have no competing interests.

\section{Authors' contributions}

$\mathrm{HC}$ designed the study and performed the virus infection and the sampling work, and wrote the manuscript. YM advised on the study design, carried out the RT-PCR and sequencing work, assisted with the analysis of data and the manuscript. TL and GC were responsible for the preparation of animals and virus, and the sampling work. JD and JM carried out the detection of antibody levels and CPE detection. All authors read and approved the final manuscript. 


\section{Acknowledgements}

This work was supported by the fund of key special projects of breeding new varieties of genetically engineered organisms (2011ZX08011-004, 2009ZX08007-008B, 2009 ZX08006-002B) from Ministry of Agriculture of the People's Republic of China.

Received: 10 June 2012 Accepted: 17 January 2013

Published: 11 March 2013

\section{References}

1. Grubman MJ, Baxt B: Foot-and-mouth disease. Clin Microbiol Rev 2004, 17:465-493.

2. Brown F: The history of research in foot-and-mouth disease. Virus Res 2003, 91:3-7.

3. Thomson GR, Vosloo W, Bastos AD: Foot and mouth disease in wildlife. Virus Res 2003, 91:145-161.

4. Belsham GJ: Distinctive features of foot-and-mouth disease virus, a member of the picornavirus family; aspects of virus protein synthesis, protein processing and structure. Prog Biophys Mol Biol 1993, 60:241-260

5. Drake JW, Holland JJ: Mutation rates among RNA viruses. Proc Natl Acad Sci U S A 1999, 96:13910-13913.

6. Domingo $\mathrm{E}$, Holland JJ: RNA virus mutations and fitness for survival. Annu Rev Microbiol 1997, 51:151-178.

7. Hedger RS: The isolation and characterization of foot-and-mouth disease virus from clinically normal herds of cattle in Botswana. J Hyg (Lond) 1968, 66:27-36.

8. Sutmoller P, McVicar JW, Cottral GE: The epizootiological importance of foot-and-mouth disease carriers. I. Experimentally produced foot-and -mouth disease carriers in susceptible and immune cattle. Arch Gesamte Virusforsch 1968, 23:227-235.

9. Zhang ZD, Kitching RP: The localization of persistent foot and mouth disease virus in the epithelial cells of the soft palate and pharynx. J Comp Pathol 2001, 124:89-94.

10. Alexandersen S, Zhang Z, Donaldson Al: Aspects of the persistence of foot-and-mouth disease virus in animals-the carrier problem. Microbes Infect 2002, 4:1099-1110.

11. Moss A, Haas B: Comparison of the plaque test and reverse transcription nested PCR for the detection of FMDV in nasal swabs and probang samples. J Virol Methods 1999, 80:59-67.

12. Laor O, Torgersen $\mathrm{H}$, Yadin $\mathrm{H}$, Becker $\mathrm{Y}$ : Detection of FMDV RNA amplified by the polymerase chain reaction (PCR). J Virol Methods 1992, 36:197-207.

13. Callens M, De Clerca K, Gruia M, Danes M: Detection of foot-and-mouth disease by reverse transcription polymerase chain reaction and virus isolation in contact sheep without clinical signs of foot-and-mouth disease. Vet Q 1998, 20(Suppl 2):S37-S40.

14. Woodbury EL, llott MC, Brown CC, Salt JS: Optimization of an in situ hybridization technique for the detection of foot-and-mouth disease virus in bovine tissues using the digoxigenin system. J Virol Methods 1995, 51:89-93.

15. House C, Meyer RF: The detection of foot-and-mouth disease virus in oesophageal-pharyngeal samples by a polymerase chain reaction technique. J Virol Methods 1993, 43:1-6.

16. Brown CC, Meyer RF, Olander HJ, House C, Mebus CA: A pathogenesis study of foot-and-mouth disease in cattle, using in situ hybridization. Can J Vet Res 1992, 56:189-193.

17. Hofner MC, Carpenter WC, Donaldson Al: Detection of foot-and-mouth disease virus RNA in clinical samples and cell culture isolates by amplification of the capsid coding region. J Virol Methods 1993, 42:53-61.

18. Locher F, Suryanarayana W, Tratschin JD: Rapid detection and characterization of foot-and-mouth disease virus by restriction enzyme and nucleotide sequence analysis of PCR products. J Clin Microbiol 1995, 33:440-444.

19. Condy JB, Hedger RS, Hamblin C, Barnett IT: The duration of the foot-and -mouth disease virus carrier state in African buffalo (i) in the individual animal and (ii) in a free-living herd. Comp Immunol Microbiol Infect Dis 1985, 8:259-265.

20. Burrows R: The persistence of foot-and mouth disease virus in sheep. J Hyg (Lond) 1968, 66:633-640.

21. Rodriguez-Calvo T, Diaz-San Segundo F, Sanz-Ramos M, Sevilla N: A replication analysis of foot-and-mouth disease virus in swine lymphoid tissue might indicate a putative carrier stage in pigs. Vet Res 2011, 42:22.
22. Scheinfeldt LB, Soi S, Thompson S, Ranciaro A, Meskel DW, Beggs W, Lambert C, Jarvis JP, Abate D, Belay G, Tishkoff SA: Genetic adaptation to high altitude in the Ethiopian highlands. Genome Biol 2012, 13:R1.

23. Simonson TS, Yang Y, Huff CD, Yun H, Qin G, Witherspoon DJ, Bai Z, Lorenzo FR, Xing J, Jorde LB, et al: Genetic evidence for high-altitude adaptation in Tibet. Science 2010, 329:72-75.

24. Hedger RS: Observations on the carrier state and related antibody titres during an outbreak of foot-and-mouth disease. J Hyg (Lond) 1970, 68:53-60.

25. Burrows R: Studies on the carrier state of cattle exposed to foot-and -mouth disease virus. J Hyg (Lond) 1966, 64:81-90.

26. Baxt B, Mason PW: Foot-and-mouth disease virus undergoes restricted replication in macrophage cell cultures following Fc receptor-mediated adsorption. Virology 1995, 207:503-509.

27. Rigden RC, Carrasco CP, Summerfield A, KC MC: Macrophage phagocytosis of foot-and-mouth disease virus may create infectious carriers. Immunology 2002, 106:537-548.

28. Salt JS: The carrier state in foot and mouth disease-an immunological review. Br Vet J 1993, 149:207-223.

29. Dawe PS, Flanagan FO, Madekurozwa RL, Sorensen KJ, Anderson EC, Foggin CM, Ferris NP, Knowles NJ: Natural transmission of foot-and-mouth disease virus from African buffalo (Syncerus caffer) to cattle in a wildlife area of Zimbabwe. Vet Rec 1994, 134:230-232

30. Dawe PS, Sorensen K, Ferris NP, Barnett IT, Armstrong RM, Knowles NJ: Experimental transmission of foot-and-mouth disease virus from carrier African buffalo (Syncerus caffer) to cattle in Zimbabwe. Vet Rec 1994, 134:211-215.

31. Malirat V, De Mello PA, Tiraboschi B, Beck E, Gomes I, Bergmann IE: Genetic variation of foot-and-mouth disease virus during persistent infection in cattle. Virus Res 1994, 34:31-48

32. Rodriguez Pulido M, Sobrino F, Borrego B, Saiz M: Attenuated foot-andmouth disease virus RNA carrying a deletion in the 3 ' noncoding region can elicit immunity in swine. J Virol 2009, 83:3475-3485.

33. Shao JJ, Wong CK, Lin T, Lee SK, Cong GZ, Sin FW, Du JZ, Gao SD, Liu XT, Cai XP, et al: Promising multiple-epitope recombinant vaccine against foot-and-mouth disease virus type $\mathrm{O}$ in swine. Clin Vaccine Immunol 2011, 18:143-149.

34. Lu Z, Cao Y, Guo J, Qi S, Li D, Zhang Q, Ma J, Chang H, Liu Z, Liu X, Xie Q: Development and validation of a $3 A B C$ indirect ELISA for differentiation of foot-and-mouth disease virus infected from vaccinated animals. Vet Microbiol 2007, 125:157-169.

doi:10.1186/1743-422X-10-81

Cite this article as: Chang et al:: Foot-and-mouth disease virus carrier status in Bos grunniens yaks. Virology Journal 2013 10:81.

\section{Submit your next manuscript to BioMed Central and take full advantage of:}

- Convenient online submission

- Thorough peer review

- No space constraints or color figure charges

- Immediate publication on acceptance

- Inclusion in PubMed, CAS, Scopus and Google Scholar

- Research which is freely available for redistribution 